\title{
ELECTROMYOGRAPHYCAL FINDINGS IN HUMAN CHRONIC CHAGA'S DISEASE
}

\author{
M. A. PAGANO \\ BUSANA BAS8O
}

\author{
G. G. ARISTIMUNO \\ A. COLOMBI
}

R. E. P. SICA

It is a well-known feature that looses of neurones occur in the autonomic and central nervous systems in human and experimental Chagas' disease $2,3,4,5,6,12$. However, only a few reports have appeared in the literature regarding the lower motoneurone state in acute Chagas' disease ${ }^{6}$ and in experimental chronic Chagas' disease 9,11 , while no mention has been made yet of the state of the motor unit (m.u.) in human chronic Chagas' disease.

In this investigation we have set out to explore the m.u. behaviour in human chronic Chagas' disease by employing conventional electromyography (EMG) in order to obtain enough data to justify the employment of other more electrophysiological techniques.

\section{MATERIAL AND METHODS}

Bighty patients were studied. Their ages ranged between 15 and 58 years. On clinical and laboratory grounds they were judged to be healthy, being the only abnormality detected the presence of at least two positive out of three serum tests for Chagas' disease. None of them have been previously submited to specific treatment.

Unrelated causes of muscle denervation were excluded by rejecting patients over the age of 601,8 and any who had had metabolic or toxic disorders known to be associated with neuropathy.

All patients were studied electromyographically. For this investigation coaxial needles (Disa, type 90113K0031) were used to sample the electrical activity induced in deltoid (d), biceps (b), abductor pollicis brevis (apb), vastus medialis (vm), tibialis anterior (ta) and extensor digitorum brevis (edb) muscles by volitional contraction. The dengities bf the interference patterns during maximum effort were analyzed subjectively and any spontaneous discharges at rest were noted.

The action potentials of fibres recruited during weak effort were fed through a low noise amplifier and dysplayed on a Akonic (type 408) electromyograph. Potentials were regarded as probably neuropathic if they possesed more than one of the following characteristics: long duration, poliphasic or fragmented configuration and enlarged amplitude.

Section of Clinical Electroneurophysiology, Hospital Ramos Mejia, Buenos Aires, Argentina. 


\section{RESULTS}

A reduced interference pattern was found in 63 patients: 34 of them had a diminished interference pattern in all the muscles explored, while the remaining 29 showed in 2 to 4 muscles a full interference pattern (Table 1).

In those muscles which showed a reduced interference pattern most of the remaining potentials were fragmented or poliphasic and had long duration, some of them hal a very enlarged amplitude. This last sort of potentials could be seen, in variable proportion, in all the muscles studied, but mainly in $\mathrm{vm}$ and ta (>than $8 \mathrm{mV}$ ).

Neither fibrillations nor positive sharp waves were recorded in any patient.

\begin{tabular}{lrrl}
\hline Muscles & D & P & L.A. \\
\hline \hline d & 8.8 & 61.2 & 17.5 \\
b & 17.9 & 62.7 & 23.9 \\
apb & 8.5 & 65.8 & 24.4 \\
vm & 34.3 & 85.7 & 54.3 \\
ta & 32.4 & 88.7 & 35.2 \\
edb & 54.2 & 93.5 & 34.7 \\
\hline
\end{tabular}

Table 1 - Electromyographic findings (\% of patients):

$D=$ diminished interference pattern; $P=$ poliphasic

or fragmented potentials; L.A. = potentials of lono

duration and exiarged amplitude.

\section{DISCUSSION}

The characteristic features of the studied patients were that all of them had positive serum tests for Chagas' disease and none had any sign or sympton which could be interpreted as due to involvement of the nervous system or any other organ. In fact, all them appeared to be healthy and had normal active lives.

However, the EMG investigation showed that most of them had some old and chronic denervation which affected muscles in the upper and lower limbs, which appeared to be subclinical since no patient complained of weakness and no clinical sign of denervation was detected.

This first approach, although limited to the EMG manifestations, was clear enough to justify a deeper investigation in these patients by employing other techniques with the purpose of obtaining more information about the involvement of the motor unit in this pathological condition (see Sanz et al. 7 and Taratuto et al. ${ }^{10}$ ).

\section{SUMMARY}

An electromyographical investigation of 80 patients with chronic Chagas' disease was made. It was found that $79 \%$ of the studied patients had EMG manifestations of old and chronic denervation of the upper and lower limbs without clinical features of nervous system involvement. 


\section{RESUMEN}

\section{Hallazgos electromiogrdficos en la enfermedad de Chagas crónica humana.}

Fueron estudiados 80 pacientes portadores de la forma crónica de la enfermedad de Chagas mediante el empleo de técnicas convencionales de electromiografía de detección. Los hallazgos evidenciaron en el $79 \%$ de los pacientes signos de denervación antigua tanto en miembros superiores como inferiores, aúnque con predominio en estos últimos. En ningún caso hubo manifestacionrs clínicas concomitantes.

\section{REFPERENCES}

1. CAMRBFLL, M. J.; Mc COMAS, A. J. \& PETITO, F. - Physiological changes in ageing muscles. J. Neurol. Neurosurg. Psychiat. (London) 36:174, 1973.

2. KOBERLE, F. - Patogenia da moléstia de Chagas. Rev. Goiana Med. (Goiana) $3: 155,1957$.

3. KOBERLE, F. - Cardiopatia chagásica. O Hospital (Rio de Janeiro) 53:311. 1958.

4. KOBERLE, F. \& NADOR, E. - Btiologia a patogenia do megaesolago no Brasil. Rev. Paul. Med. (São Paulo) 47:243, 1955.

5. Magarino torRes, C. B. - Patogenia das lesóes do miocárdio na doença de Chagas. Rev. Golana Med. (Golania) 4:121, 1958.

6. MAGARINO TORRES, C. B. \& VILLACGA, J. - Encefalite e mielite causadas pur um tripanosoma (T. Crus). Mem. Inst. Oswaldo Cruz (Rio de Janeiro) 11:80, 1919.

7. SANZ, OLGA; RATUSNU, A. F.; ARISTIMUNO, G. G.; O'NEILL, E. \& SICA. R. E. P. - An electrophysiological investigation of the skeletal muscle in human chronic Chagas' disease. Arq. Neuro-Psiquiat. (SẼo Paulo) 36:319, 1978.

8. SICA, R. E. P.; SANZ, OLGA \& COLOMBBI, A. - The effects of ageing upon the human soleus muscle. Medicina (Buenos Aires) 36:443, 1976.

9. SCHWRTZLRUD, H. \& KOBERLE, F. - Chagas myelopathie. Zschr. f. Tropenmed. u. Parasit. 10:309, 1959.

10. Taratuto, analta; Pagano, M. A.; FuMO, Teresa; sanz, olga \& sica, R. E. P. - Histological and histochemical changes in the skeletal muscle in human: chronic Chagas' disease. Arq. Neuro-Pgiquiat. (Sto Paulo) 36:327, 1978.

11. VICHI, F. L - Destrulçáo de neurônios motores na medula espinal de ratos na fase aguda da moléstia de Chagas. Rev. Inst. Med. Trop. sáo Paulo 6:150. 1964.

12. VILLELAa, E. - Moléstia de Chagas: forma nervosa. Folh. Med, (Rio de Janeiro) 4:49, 1923.

Reprint request: Dr. R, E. P. Sica - Seccion de Electronourofisiologia Clinica - Hospital Ramos Mejia - Urquiva 609 - Buenos Aires - Argentina. 